\title{
The Military Forces Of The Nations Of Europe
}

\section{Captain Martin Petrie}

To cite this article: Captain Martin Petrie (1861) The Military Forces Of The Nations Of Europe, Royal United Services Institution. Journal, 5:16, 45-67, DOI: 10.1080/03071846109416743

To link to this article: http://dx.doi.org/10.1080/03071846109416743

央 Published online: 25 Sep 2009.

Submit your article to this journal $\pi$

Џ Article views: 4

Q View related articles ๔ 


\title{
Friday, February 15 th, 1861 .
}

\author{
Colovel PIIILIP J. YORIE, F.R.S., in the Chair.
}

\section{TIIE MILITARY FORCES OF THE NATIONS OF EUROPE.}

\section{By Captaix MARTIN PETRIE, 14th Regt. Topographical Staff.}

IT will be my endeavour to-day to give some account of the Military Forces belonging to the several European powers.

At the present time, we can hardly be unconscious of the immense develepnent which the warlike resources of each nation are receiving every day, and the great and growing importance attached to the naral and nilitary element by the governments of every state in Europe; one nation striving to rival another in the extent and the perfection of its armaments. $\Lambda$ dministrative talent was never so severely taxed to increase the personnel available for an army; and the powers of science and art are exerted in an equal proportion, to originate new implements of destruction, or to devise means of safety from their tremendous effects.

Abroad, the miglity engine of the conscription extends its resistless grasp in every direction; whilst at home, the free youth of Britain respond to their country's call-the gleaming bayonet is a welcome ornament in the quiet hamlet or the mart of industry, and one smile of acknowledgement from a monarch whose securest home lies in the hearts of her people, is deemed an ample reward for every exertion and fatigue.

While the marshalling of men is proceeding thus, fresh fortresses are rising through the length and breadth of Europe; colossal walls of stone, and even of iron, with tortuous labyrinths of ditches, spread far and wide, in the endeavour to guard each point vulnerable to a foe.

'The ocean, once speckled with the white flowing canvas and tall masts of our wooden castles, in these days bears on its surface the huge smoking armadillo of iron, less picturesque, but more mischievous; and, when we come to the workshop, we find mechanical contrivance no longer limited to the crude weapons of a few years since, but creating. structures whose vast proportions the Titans might envy, yet whose delicacy of finish the most expert fairy could hardly excel.

France, though professedly not arming, or placing her forces on a war footing, is straining every nerve to bring her troops to the lighest state of efficiency, to have them prepared for action at a moment's notice, and "in a condition to meet all emergencies." The matériel of her army is being improved and remodelled with all the aids that science or ingenuity can suggest, and her naval arsenals resound with the echoes of ten thousand lammers, under the strokes of which not less than thirteen iron floating 
batteries are gradually rising to completion; these, when launched, will form a most formidable addition to the already powerful inaritime forces of the country.

Prussia, too, is endeavouring to organize licr army on at more effective basis than hitherto, to improve the arms and equipments of all branches of the service, and to strengthen her frontier fortresses in every manner that is practicable.

Austria, though exhausted and shaken by the events of the last two years, is, nevertheless, making ready for a contest; the points open to attack will now be strengthened with worlss on the newest principles of art, while the famed Quadrilateral bristles with bayonets, and the Kaiser is preparing to confront the louring storm.

Italy tells us of a million of bayonets to be assembled in the approaching spring, to consummate the vindication of that national existence, which has so long been the aspiration of her statesmen and the theme of her poets. Mysterious cargoes of arms and warlike stores are stealing enstwards to the Principalities, with the view of effecting such a diversion in Hungary as shall compel Austria to relax her eagle grasp upon Venetia.

Nor is the Colossus of the North idle. Profiting by the experience of the late war, the Czar Alexander is endeavouring, while reducing the numbers of his unwieldy lerions, to increase their efficiency by adopting all possible improvements both in the adninistration and the material of his forces; and, though foiled in his ambitious projects of territorial aggrandisement in the West, is advancing by gigantic strides along the coasts of the Pacific Ocean, and gradually enveloping the northern provinces of the Chinese Empire.

The secondary powers of Europe, also, are not indiferent. The Spaniards, the Belgians, and the Dutch are "sharpening their cutlasses," as Sir Charles Napier would have said ; and the Daues, still more active, are conmissioning their navy, and placing their regiments upon a war footing, determined to show their opponents that now, at all events, "there is nothing rotten in the state of Denmark."

Europe, as it is at present politically divided, consists of fifty-two separate kingdoms and states, the largest of which is Russia, and the smallest the little republic of Andorra, situated somewhere among the snowy peaks of the Pyrenees; the military power of this last, however, can be safely regarded as of no grent weight in European combinations.

Of these states we may reckon five whose military and political strength entitles them to be called First-rate Powers. 'They are-

$\begin{array}{ll}\text { Austria, } & \text { Russia, } \\ \text { Prussia, } & \text { France, }\end{array}$

Great Britain.

To the five we hope soon to see a sixth added. I allude to the Fingclom of Italy, which, despite all obstacles, promises ere long to 
lecome an influential country, with a government, less paternal it is true, but more constitutional, than those of its neighbours, whose exertions in the cause of "order" are continually producing such violent convulsions. Let us trust that the Italian nation, which has already won the warmest sympathies of all Englishmen, may ever be our allies in arms.

I shall commence with a notice of the German powers, reserving a view of our own land to the last.

Austria and Prussia are, as you well know, the two leading states of the Gurmanic Confedcration. This latter body may be considered as the existing representation of the old Gorman Enpire, and includes no less than thirty-six separate kingdoms and duchies. Its extent is defined by the red tint upon the map.

The present constitution dates from 1815 , but it has since undergone some modificntions.

You will observe that Posen and Prussia Proper do not form part of the confederation; neither do IInngary, Gallicia, the Austrian provinees bordering upon Turkey and the Adriatic, nor Venetia. On the other hand, the Duchies of Luxemburg and Limberg belonging to the Netherlands, and Holstein, which appertains to Denmark (in virtue of the king of that country being its duke), are constituent portions of the Federal territory.

'The fortresses of Mayence, Luxcmburg, Landau, Ulm, Kchl, and lastadt are Federal strongholds, and always garrisoned by mixed contingents.

'The species of divided allegianco thus engendered constantly' gives rise to political complications. TVe are just witnessing an example of one of these in the Schleswig-Holstein question.

The territory of the Germanic Confederation includes an area of 243,000 square statute miles, and has a population of $44,000,000$.

The principal provisions of the Federal military laws are as follows:-

In time of peace, the general supcrvision and control of the army is vested in a committee of the Diet, in conjunction with a consultative military commission. 'The actunl command of the forces, hawever, is exercised by the governments of the various states.

Upon a declaration of war, the authority of the several German princes over their troops ceases 'and determines, and the supreme command devolves upon the Diet, by whom are appointed the commander-in-chief, and several other principal officers. From this body also all orders relative to the distribution, movements, and action of the Germanic forces emanate.

The strength of the contingents to be furnished by the different states is fixed at $1 \frac{2}{3}$ per cent. of the population as it existed in 1815 , or about 1 per cent. of the present population.

The contingents furnished are divided into three classes:-

1st. The Principal Contingent.

2nd. The Reserve Contingent.

3rd. The " Frsatz" Contingent.

This latter forms the depôts from which the casualties in the other two contingents are to be replaced.

The principal and reserve contingents are always to be maintained in such a state of efliciency as to be ready to take the field in fill strength 
within five wecks after receiving their orders. Efficient provision must also be made for embodying the "Ersatz."

The laws passed in 1821 and 1822 fix the relative proportions of the various arms as follows:-

One-eighth of the total strength to be civalry, one-hundredth to consist of pioncers and engineers, and the proportion of artillery one gun for every 400 men.

The Federal siege-train to consist of 100 guns, 30 howitzers, and 70 mortars. Each corps-d $l$ armée to have a pontoon train for a bridge 400 feet long, besides smaller pontoon equipments for divisions.

The total forces ought to number 503,000 men of all arms; but the numbers at present forthcoming are considerably larger: the inspection returns of 1858 showed no fewer than 560,000 effectives.

The Federal grand army is divided into nine separate corps-d'armée, each of which is from 40,000 to 60,000 strong, besides a division of reserve infantry.

The 1st, 2 nd, and 3rd of these are furnished by Austria, and number $158,037 \mathrm{men}$.

Prussia gives the 4 th, 5 th, and 6 th, with a total of $133,769 \mathrm{men}$.

The 7th is supplied by Bavaria, and is 59,334 strong.

The 8th by Wurtemberg, Baden, and Hesse Darmstadt, and includes 50,251 .

Saxony, Hesse Cassel, Nassau, Limberg, and Luxemburg.furnish the 9th, which numbers 38,281 .

And the 10th consists of the contingents of Hanover, Brunswick, and seven smaller states, and has a strength of 45,746 .

The reserve infantry division is made up by fifteen of the minor states; its force is 17,656 , and it is destined to furnish garrisons for the Federal fortresses during war.

I shall not attempt to recapitulate the strength and composition of the contingents required from the various states individually, but I may mention that each has to contribute a division; brigade, battalion, or even a single company, according to its size and population. The separate fractions of the force thus set on foot are in all cases complete with cavalry, artillery, engineers, pontooners, train, commissariat, field bakeries, hospital equipment and attendants, \&c.

The contingents of contiguous states are frequently united in the autumn to practice mancuvring on a large scale, and the various divisions of the forces are inspected annually.

With the view of rendering these inspections as inpartial as possible, the general, or other superior oflicer, always belongs to a different state: thus, the Austrian forces would be inspected by a Prussian or Bavarian general, and the same principle is observed throughout.

I have thus endeavoured to give a brief outline of the military constitution of this rather cumbrous and complieated confederation, which, no doubt, looks very perfect on paper; but it is needless to say that its effectiveness in time of emergency must entirely depend upon the cohesion and unaninity prevailing among its component parts.

In practice, its organization presents many anomalies: for example, no state has, or should have, a right to employ any Federal troops, or indeed 


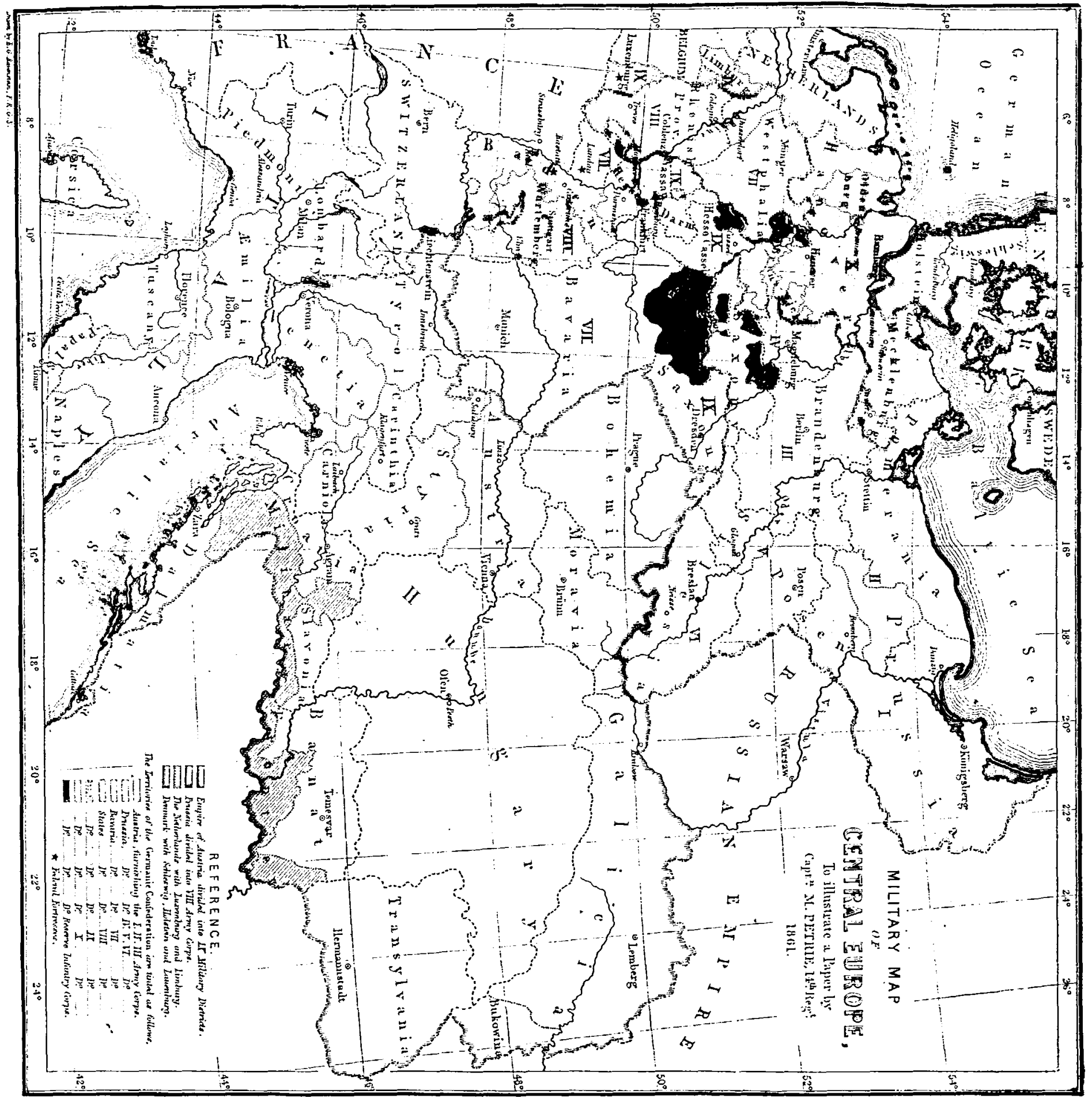


* troops recruitcd upon Federal territory, in a war carried on by itself undependently. Yet in the campaign of 1859 Austria collected almost all her German forces in Italy, garrisoning. the Federal proyinces with Hungarians, Croats, and Italians. This proceeding was not then objected to, it being considered that the contest was indirectly in the cause of Cermany as a whole.

I may perhaps observe, that in one of the semi-oficial pamphlets whicli lately appeared in Paris, it was laid down as a principle, that if Germany generally were to acquire the consistency of a single porrer, France would consider it necessary to place the Rhine between herself and it, in order to provide security against so formidable a neighbour; but that at present the martial array of Germany might be regarded as rather a harmless affuir than otherwise.

\section{Atstria,}

The empire of Austria extends over an area of 257,000 square statute miles, and lias a population of $35,000,000$. This is of course exclusive of Lombardy.

I have already stated that Austria furnishes three corps-cl'asmée, amounting to 158,037 men, to the Germanic Confederation.. This is, however, but a small fraction of the numbers that can be brought into the field in case of war, for they amount to nearly 740,000 men of all arms.

- The Austrian army is recruited by the conscription, to which every province of the empire is subject. Exemptions are however granted, in favour of all ecclesiastics and students of theology, government employés, graduates of universities, and holders of entailed estates, besides others who can prove their presence to be necessary for the support of their families.

The conscripts are summoned to the ranks on attaining the age of twenty; they are required to serve eight years with the active army, and then for two years with the reserve.

The government engages to procure substitutes for a sum varying from $\mathfrak{£ 4 0}$ to $£ 150$; but it should be remarked that this bounty is only paid to the substitute on the termination of his engagement; the interest at 5 per cent. is, however, added to his pay while serving.

The war establishment of the Austrian army, according to the organization that came into force in April, 1860, is as follows:-

$$
\begin{aligned}
& 309 \text { Battalions of Infantry - } \quad-\quad-\quad-437,964 \\
& 11 \text { Regiments of Cavalyy - - - - } \quad \text { - 60,110 } \\
& 136 \text { Batteries of Artillery - - - - } \quad \text { - 27,176 - 1,088 } \\
& 2 \text { Regiments Engineers - - - - } 7,460 \\
& 6 \text { " Pioneers - - - - 6,858 } \\
& 24 \text { Squadrons Train - - - } \quad \text { - 18,204 } \\
& 10 \text { Companies Sanitary Corps - - - 2,550 } \\
& \text { Staff Corps, Corps of Adjutants and General } \\
& \text { Staff - - - - - - - 3,889 } \\
& \text { Total Regular Army - } \quad \text { - } \quad \text { - 564,211 }
\end{aligned}
$$




$$
\begin{array}{rlr}
\text { Brought forward } & - & -564,211 \\
\text { Volunteer Corps organized in 1859 } & - & -30,000 \\
\text { Dep6ts and Reserves of all Arms } & - & -103,751 \\
\text { Gendarmerie, Police, Veterans, \&c. } & - & -40,382 \\
\hline \text { Grand Total of Forces } & - & -\mathbf{7 3 8 , 3 4 4}
\end{array}
$$

Among the 309 battalions of infantry are 29 of grenzers or frontier troops. Thee belong to the dietricts of Croatia, Slavonia, and the Banat, which border on Turkey. The inhabitants receive allotments of land from the government, and have to render military service in lieu of rent. The land itself belongs to the communes, who cannot sell or otherwise alienate it.

Each district containing 70,000 inbabitants, is obliged to contribute a regiment, every male inhabitant being liable to serve on attaining the age of twenty years.

During peace, the frontier troops are required to perform the local and police duties of their district, and receive no pay.

In case of war the whole force may be called ont for service in the field, when they are placed upon the same footing as regards pay, dc. with regiments of the line.

The various nations composing the Austrian empire are represented in the arny in the following proportion:-Germans, 26; Chechians, 191; Ruthenes, 10; Poles, 71 ; Croats, $5 \frac{1}{2}$; Slovenes, $4 \frac{1}{2}$; Servians, 4; Italians, $11 \frac{1}{2}$; Rumanians, $4 \frac{1}{4}$; Hungarians, $6 \frac{1}{2}$; Jews and Gypsies $\frac{3}{4}$ per cent.

The ratio in which they exist in the general population of the empire is as follows:-Germans, 21.7; Chechians, 16; Ruthenes, 8; Poles, 5.6; Servians, $3 \cdot 9$; Croats, $3 \cdot 6$; Slovenes, $3 \cdot 2$; Italians, $15 \cdot 2$; Rumanians $6 \cdot 6$; Hungarians, 13.3; Jews, 2.6; Gipsies, 0.2 ; Greeks, Albanians, \&c. 0.1 per cent.

\section{Prussia.}

After Austria, the most cunsiderable of German powers is Pruseia, whose somewhat scattered territories extend from the Nicmen to the frontiers of France, and embrace an area of 108,376 square statute miles.

The population is 17,202,000, or about half that of the Austrian Empire, but the army that can be set on foot in case of war is nearly as numerous as that of the latter country.

The Prussian army is recruited by the conscription, to which every male subject becomes liable on completing his twentieth year. Exemptions are only granted to the clergy, and to others whose family circumstances require them to remain at their homes.*

Recruits have to serve for three years in the standing army, out of which however, they are generally allowed to go on furlough during the last year. They then belong for three years to the War reserve. This is only called out in the event of the army being mobilized, to raise the regiments to their full strength. Having thus belonged to the regular army for

* Young men of respecta lity and education are allowed the option of joining the army as "Freinilliger," or Yolunteers, who serve for one yenr only, but receire no pay or rations.
They usually afterwards pass an exnmination as Landwehr officers. 
ix gears, soldiers pass into the 1st han of the "landwehr" for seven years, and from that to the 2 nd ban for a similar period.

The 1st ban of the landwehr is called out in case of war, and joins the regular army in the field. During peace, the men meet twice in each year, at what are termed control meetings. Every second year they are assembled for a fortnight's drill, and every four years they have to assist at manceuvres on a large scale for a month.

The 2nd Ban of the landwelr are not assembled for training in time of peace. If called ont during war, they would principally serve as garrison troops.

As every Prussian regiment is raised in a particular district, the laudwehr regiments are composed of men who have already been accustomed to act together, and they are fully as efficient as those of the regular army.

In case of any great emergency, the "landsturm," consiating of all men from 17 to 50 years of age, may be called out; but this force has at present no organization.

The War Establishment of the Prussian army is as follows:-

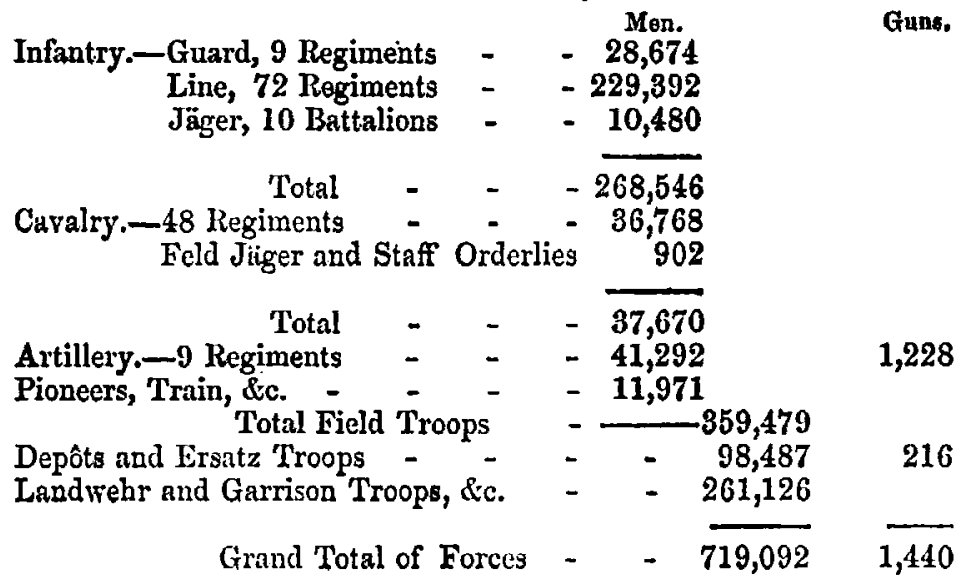

Last year the Prussian government wished to modify the laws on military service, so as to secure a fuller control over the army - to make it, in fact, more royal and less national. With this view a bill was presented to the Legislature, extending the term of service in the regular army to eight years, of which threc were to be passed with their regiments by the infantry and artillery, and four by the cavalry; and the term of service in the landwehr to be reduced to eleven years. This bill was amended in committee, and subsequently withdrawn, but its provisions have notwithstanding been acted upon to a great extent.

'The landwehr element has never been very much to the taste of the Prussian government, as the men have often shown a strong disposition to have their own opinions, when called upon to act. When employed against the insurgents at Baden Baden in 1848, they manifested so much hesitation in attacking the revolntionary troops, that it was needful to 
stimulate their zeal by the sight of a battery of artillery drawn up in their rear, and ready to open its fire upon them.

The forces of the thirty-four remaining states of Germany must be considered to possess a collective, rather than an individual importance, as they are all units in the Confederation, and not one of them could make war without the sanction of the central authority. In fact, we may regard Austria as the only German power that can bring an army into the field, and undertake a war, on her own account. And even this is doubtful; for had the war in 1859 been prolonged, the rest of Germany must have been drawn into the contest; a fact which was in no small degree instrumental in bringing about the peace of Villafranca. As it was, Trieste and the adjacent coast, being Federal property, could not be blockaded by the allied fleets, nor could Verona be besieged, without nuch embarassment, for the Confederation boundary line runs within a short distance, and any Austrian force acting against the besiegers would have found a safe sanctuary within it, issuing and retiring again as they pleased.

With regard to Prussia, though her forces are numerically very strong, yet I think we can hardly avoid the conclusion that they should only be viewed as an integral fraction of the German army. Her geographical position and political sympathies, would hardly admit of her undertaking any military operations, in which it was considered that the interests of the Fatherland generally were not involved. In the present difference with Denmark, Prissia is only acting as the representative of the other German states, whose troops would join hers in the event of hostilities against Holstein.

It is true that Prussia threatened to go to war with Switzerland about the Neufchattel question in 1847. The order for the mobilization of the army was in fact signed by the king, and was to have been issued the next morning; but the arrival of a telegraphic despatch from Berne, announcing that the Diet ceded the points demanded, prevented the decree from being put in force. Now, the king had declared that military operations would take their course if the army were once mobilized; yet I am inclined to think that the threat was rather an empty one, as a glance at the map will show that half $\dot{a}$ dozen intervening duchies must have been traversed, before the Swiss frontiers could be reached, and the sovereigns of these were not at all favourable to the Neufchutel crusade, and would hardly have given their consent. In fact, Prussia was after all obliged practically to abandon the ground she at first took up.

\section{Russia.}

Russia, as you are aware, is the largest of the countries of Europe, containing an area of $8,325,311$ square statute miles, which is five times the superficies of the rest of Europe put together.

The census taken after the late war showed the population to number $68,931,728$; of these 900,000 belonged to the nobility or privileged classes, $53,426,216$ citizens, and $21,000,000$ serfs. 
The Russian army is the most numerous and most complicated in its organization of any in Europe.

The aggregate numbers of the Russian forces have varied considerably within the last few years. Before the war, the imperial muster-rolls contained 1,140,000 men of all arms; in 1855 the number approached $2,000,000$; but it has since been much reduced, and the present strength is about 850,000 .

The army consists of the following principal divisions:-

The Active Army.

The Reserve.

Garrison Troops.

Irregular'Troops, composed principally of local corps of Cossacks.

The Russian regular army is recruited by conscription, and there are three general recruiting divisions.

1st. The Polish provinces.

2nd. The western zone of the empire, including Lithuania, Volhynia, Podolia, Kharkov, Little Kussia, and the Baltic provinces.

3rd. 'The eastern zone, embracing the rest of the empire, as far as Khamschatka.

In Poland every able-bodied inhabitant between the ages of twenty and thirty may be taken as a soldier, and no exemptions are granted to the nobility; a special tax is levied for conveying the recruits to the depôts.

In the rest of the empire, the landed proprietors have to furnish recruits from among their serfs, to send them to their depôts at their own expense, besides paying $£ 12$ towards the outfit of each.

The regular active army of Russia is organized as follows:-

1st. 'The Corps of the Imperial Guard.

2nd. The Corps of Grenadiers.

3rd. The six Permanent Corps d'Armée.

The corps of the Imperial Guard in the present pence establishment, consists of-

3 Divisions of Infantry.
2 Cavalry.
3 Brigades of Artillery.
1 Battalion of Sappers.

Each infantry division consists of 2 brigades, and I battalion of rifles. Each brigade is composed of 2 regiments.

A cavalry division contains 3 brigades of 3 regiments each. Each brigade of artillery consists of 2 batteries of 8 guns each.

The total strength of the Imperial Guard, as thus constituted, is 41,845 men, and 48 guns.

The corps of Grenadiers is also made up of infantry, cavialry, artillery, sappers, \&c., and numbers 30,321 men, with 60 guns.

Each of the 6 corps darmée consists of-

3 Infantry Divisions.

1 Cavalry "

1 Artillery ", 
Every infantry division comprises 2 brigades of 4 regiments each, besides a battalion of rifles.

$\Lambda$ cavalry division consists of 3 brigades of 2 regiments each. The first of these is invariably a dragoon brigade.' The second a lancer brigade, and the third a hussar brigade.

The artillery division consists of -

1 Horse Artillery Brigade of 2 batteries.

3 Foot " " 4 batteries each.

1 Park brigade of ". 3 batteries.

A corps d'armée thus composed should have a total establishment of nearly 50,000 men and 84 guns, but the strength of the regiments and squadrons has lately been so much reduced, that each corps does not bear more than 20,000 effectives upon its rolls.

The war establishment of the whole active army, formed of the eight corps d'armée, is 520,523 men, and 1,160 guns.

The garrison troops of Russia forn a separate corpls ctarmée. They are all infantry; and are composed of men not physically fit for the rank and file of the active forces. They furnish garrisons to various towns and posts, guards for public establishments, and do escort duty for short distances; their total number is about 100,000 .

'The general distribution of the Russian regular army is as follows :-

The corps of the Guard is stationed in and around St. Petersburg.

The corps of Grenadiers at Moscow, Vladimir, and Riazan, in the centre of European Russia.

The 1st, 2nd, and $3 \dot{d}$ corps (Tarmée are stationed along the western frontier.

The 4th and 5th in Volhynia, Podolia, and Bessarabia.

The 6th along the Volga, on the confines of Siberia, so as to be equally ready to act either in the Caucasus, or in Central Asia. One division of this corps is at present serving in the arny of the Caucasus.

As the actire army of Russia is destined to deal with the forces of the various European powers, there is a vast array of irregular or rather local forces organized for service in the interior, but especially on the eastern and southern frontiers. In these all three arms of the service are represented, but the cavalry is generally the preponderating force.

The Russian irregular troops may be divided into two distinct branches.

1st. The Cossacks of the Don, composed of fifty-seven regiments of cavalry, in addition to a regiment of cavalry and a battery of artillery, attached to the Imperial Guard at St. Petersburg.

The other branch consists of the whole of the rest of the irregular corps, with the exception of the Cossacks of Azov.*

Many of these irregular corps, which extend across the Russian empire from the Chinese frontier to the Black Sea, are formed into corps ciarmé for service in Asia.

- The Cossacks of Azov are borne upon the muster rolls as a corpe of eavalry, but in reality they are marine artillery, for service in the Black Sea. As the treaty of Paris forbids any naval forces being maintained there, they are at present doing duty on hoard of the vessels of the Odessa Steam Navigation Company. 


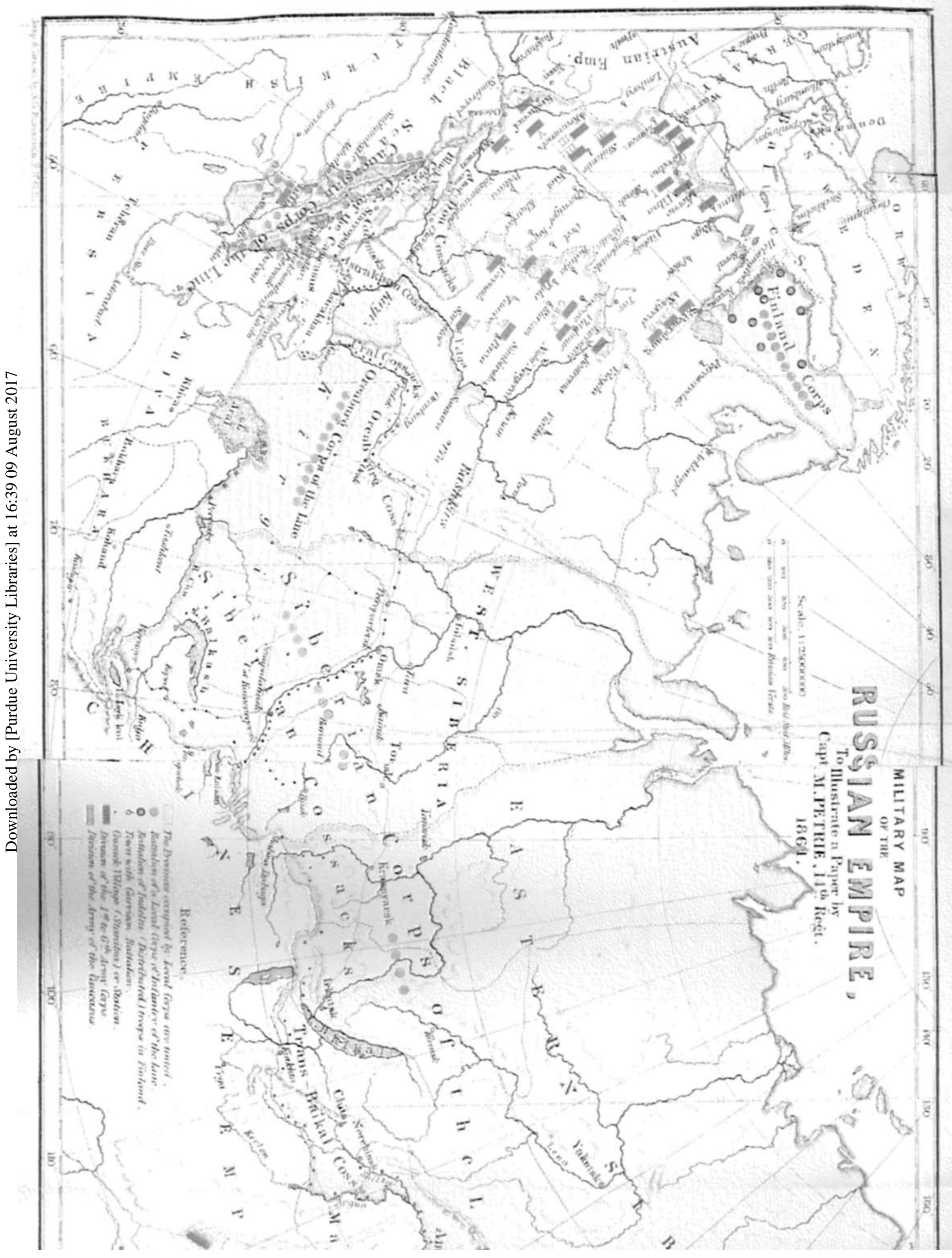




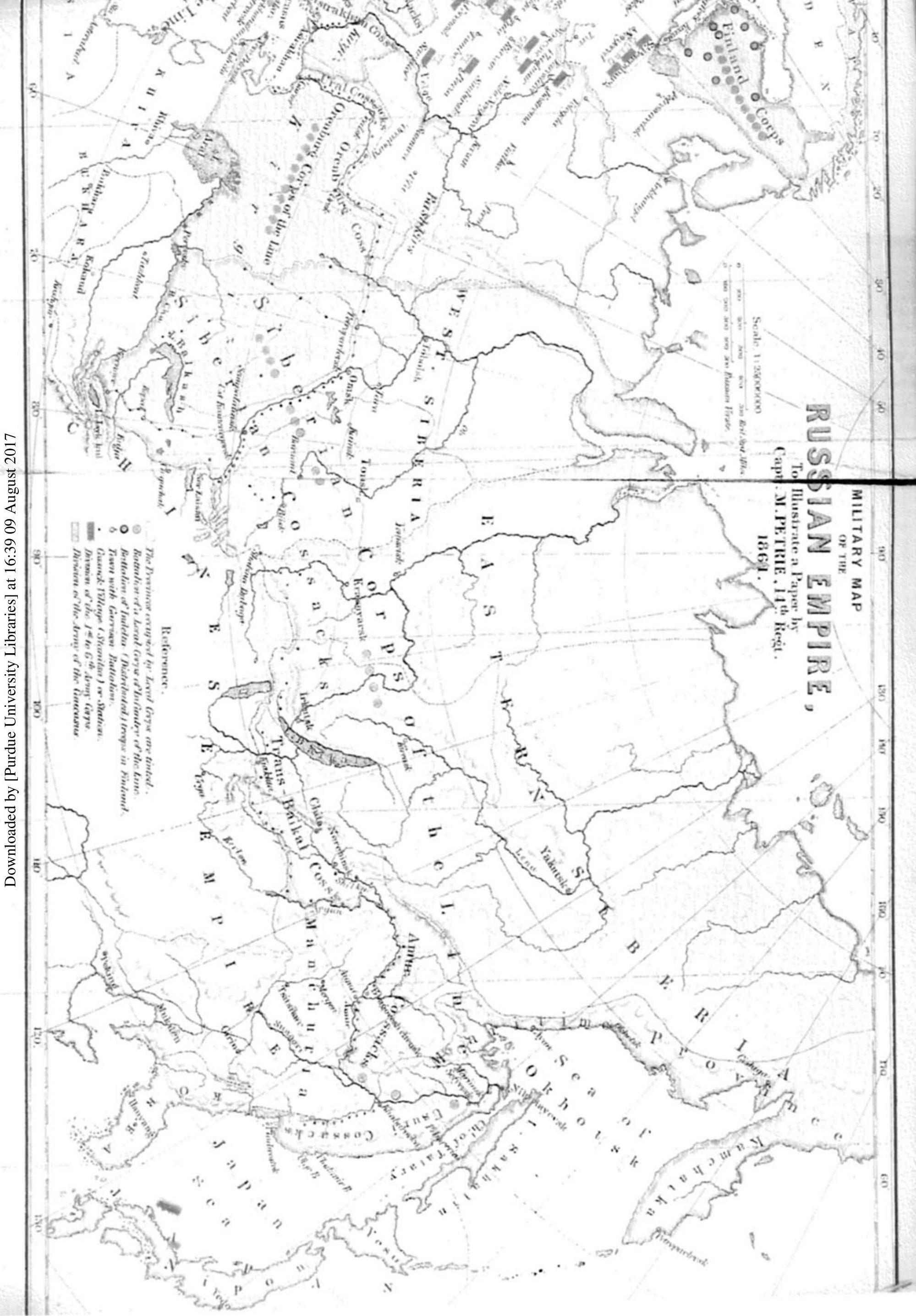


We enumerate them as follows :-

Cossacks of the Don.

Cossacks of the Black Sea.

Cossacks of Azov.

Cossacks of Astrakhan.

Cossacks of Oremberg.

Coseacks of the Oural.

Cossacks of the Siberian Frontier.

Cossacks of the Trans-Baikal.

Their total force may be estimated at 150,000 men and 200 guns.

The army of the Caucasus is a permanent local army, and consists of four divioions of regular infantry, one of which belongs to the .6th corps d'armée, one divizion of grenadiers, one of cavalry, besides the irregular troops of the line of the Caucasus. Its strength is about 120,000 men with 200 gune.

The present advances of Russia in the direction of India and China are a source of no small concern to England ; it may be interesting, therefore, to take aview of the troops that are pushing their way to conque ${ }^{2}$ in these regions, and steadily, though silently, spreading the mantle of the Russian empire over the independent tribes of Central Asia.

First, there is the corps of Oremberg, constituting a regular corps darmée. The Russian returns give its strength thus :-
17 Battalions of Infantry - $\quad$ - $\quad$ - 18,511
12 Regiments of Cossacks - _ $\quad$ - 10,652
3 Batteries Horse Artillery - $\quad$ - $744-24$ Guns.

Its real strength, however, is probably much greater, as it was this corps that in 1853 reduced half of Tartary into subjection to Russia for the first time.

Secondly, there are the Cossacks of the Oural; this corps occupies a central position between Europe and Asia, and can act as a support to the corps of Oremberg: the returns of it give about 8,800 incn and horses.

The corps of the Siberian frontier furnishes a military cordon along the south of the Sibarian territory. It consists of $9,584 \mathrm{men}$, composed of 10 regiments of cavalry and 24 guns.

But the most important of the Russian Asiatic corps is that of TransBaikal, * occupying the district through which the Amoor river runs.

Though one-third of the circumference of the globe separates this pro: vince from St. Petersburg, we nevertheless find the Northern Colossus in full activity, and within the last fow years the Russian frontier has advanced southwards along the western coast of the Sca of Japan, to the extent of not less than 600 miles. In the present condition of the Celestial Empire, we should not be surprised if the double-headed cagle, ere long, supplants the dragon in the Yellow Sea.

The Trans-Baikalian corps is a new creation, and its organization has been pushed with great activity within the last few years. Its present

- So called from its paition bejond the lake Raikal. 
strength would enable operations to be undertaken against China with ease. It is composed of infantry and cavalry only-the want of roads, and the enormous distance from Europe, forbidding the creation of artillery.

It numbers at present $17,000 \mathrm{men}$, but is to be raised to 30,000 .

We thus see three distinct armies progressing eastwards and southwards; doubtless in the hope of one day securing the command of the western shores of the Pacific, on the one hand, and on the other, of threading their way through the defiles of the Hindoo Koosh, and debouching eventually upon the plains of Hindostan.

Until the year 1854, the actual state of the Russian forces was a species of enigma. We heard of a fabulous array of regular troops, and endless tribes of Cossacks; but it was hinted that this army existed chiefiy on paper, and a distinguished statesman talked very comfortably of "crumpling up" Russia. Upon trial, however, the "crumpling up" process was found to lacerate our own hands not a little, and the Russian troops showed a discipline and a constancy for which few had given them credit.

Last year the Russian government published for the first time a detailed statement of the cost and strength of their military cstablishments.

This document shows that every effort is being made to augment the efficiency, and to raise the character and morale of their soldiers.

The military colonies have been abolished, and the laws that constituted military service a punishment for various crimes have been abrogated. The sons of soldiers; borne on the rolls as "fils de troupe," and who number 578,000 , have been exempted from entering the army. The pay has been increased, and a scale of pensions established. Regimental schools and gymnasia have been organized, and a variety of other useful measures of reform adopted.

The arms also have been improved, rifles have been largely introduced throughout the service, and schools of musketry established.

The artillery likewise is being furnished with rifled guns.

\section{ITALY.}

Only two years since, Italy was a geographical expression, and consisted of eight separate states, viz. the Two Sicilies, Sardinia, Tuscany, the Papal States, Parma, Modena, the Principality of Monaco, and the Republic of San Marino.

The united war establishments of the armies of these amounted to $305,000 \mathrm{men}$, of which the Two Sicilies furnished 143,000, Sardinia 112,000. The forces of San Marino were just 40 men.

At the present moment the Italian national banner waves over the whole Peniusula, from the Alps to Cape Passaro, with the exception of Venetia and the Roman territory held by French troops. Upon Victor Emmanuel will devolve the undertaking of organizing the Italians, already united by the ties of "blood, language, and religion," into a single nation. In this task does not nearly every Englishman heartily bid him "God "peed ?"

The Sardinian army as it existed in 1858 could place, as I have said, $112,000 \mathrm{men}$ in the field. This force was recruited by conscription, which extended to the insular portion of the kingdom, and to which all classes 
wre liable, irrespective of rank, excepting a limited number of students the holy orders. Exemptions on account of family circumstances were, however, granted on a liberal scale, and exoneration from serving was pormitted to be purchased for $\mathbf{1 2 0}$. The number of males annually ataining their twentieth year was 52,000; of these 34,000 were excused, or were physically unfit, leaving an available contingent of $18,000 \mathrm{men}$.

This contingent was divided into two classes, or categories. The first, consisting of those who had drawn low numbers, joined the standing army, in which they served for five years, and were then allowed unlimited furlough for six years, after which their military liabilities ceased. The second class were only called out for training during forty-two days in each year, and were free after five years. In case of war, those of the first class on furlough, and the whole of the second class, were called out, to place the regiments and squadrons on a war footing.

It is now intended to apply the conscription to the whole peninsula; and calculating from the numerical returns of the population, the Italian forces ought eventually to show a muster of not less than 600,000 . At present, however, as the armies of the late princes have been disbanded, and there are no classes of previous years available over a large portion of the peninsula, we cannot reckon upon a strength of more than 400,000 . Considerable difficulties will lie in the way of carrying the conscription into effect over the whole of Italy and Sicily, as neither the latter island nor the Papal States have hitherto been subjected to it under their late governments; and its cnforcement in these provinces will in all probability cause considerable excitement and opposition.

Possibly it will amuse you to learn a reply given by the Pope to General Lamoricière, when the latter told lim he never could hope to raise an adequate army without resorting to compulsory service; he said that he had conscientious scruples on the subject, not considering it right to impose celibacy on any one. 'You are aware that abroad permission for soldiers to marry is a rare privilege. 'The inconsistency of the statement, as proceeding from his Holiness, hardly requires comment.

With regard to the efficiency of the future army of Italy, doubts may be entertained whether it will be as good as the type from which it takes its origin. The campaign in the Crimea showed the excellent spirit and organization of the Sardinian troops, and Lombardy and Romagna will no doubt furnish equally good material. The Tuscans, however, are too soft and effeminate to make very brilliant soldiers, and the change for the worse becomes greater as we proceed southwards, the army of the Two Sicilies never having been supposed to possess any military qualities worth mentioning. Apropos of this, I will relate an andedote of King Frnncis the First. When he was on one occasion complimented on the martial bearing and soldierlike appearance of his troops at a review, he dryly replied, with a shrug of his shoulders, " $\mathrm{Si}$, leoni in citta, ma lepri in campagna." On another occasion, when a proposition was made to him to have the breasts of the soldiers' coats quilted with cotton, in order to enable them to resist sword-cuts the' more effectually, his answer was, that he would suggest the quilting should be applied to their backs, as they were the part invariably presented in action to the enemy.

Let us hope, nevertheless, that a just and equable administration, and a 
consciousness of the cause in which they bear arms, being that of their newly enfranchised nation, and not of an unprincipled and arbitrary despot, will inspire them with zeal to emulate the deeds of their more northern brethren.

Framoe.

Perhaps of all the European armies the one which possesses the highest interest for England is that of France.

Including Savoy and Nice, but excluaive of Algeria, the empire contains 212,893 square statute miles, and had a population in 1856 of $36,877,800$.

The army that can be put on foot in case of war, numbers about 626,000 , besides 10,000 local and colonial troops and 6,550 marines kept in the French possessions abroad.

The French army is chiefly recruited by conscription, the contingent required being fixed annually by imperial decree, and the proportion to be furnished by each canton is regulated by the numbers inscribed upon the "Listes du Tirage" as having completed their twenty-first year within the preceding twelve months.

In 1855 the contingent was fixed at 140,000 men. The total number inscribed was 306,622 , which were accounted for in the following manner:-

$$
\begin{aligned}
& \text { Exempted on account of family circumstances - 42,457 - Per Cent. } \\
& \text { Rejected on account of being under the stan- } \\
& \text { dard height of } 5 \text { feet } 1 \text { inch - - }-17,951-5.85 \\
& \text { Rejected on account of being physically unfit } \\
& \text { for the service - }-\overline{-} \text { - }- \text { iberated unconditionally, being over the } \\
& \text { number required - }-\quad-\quad \text { - 45,974 - } 15.00 \\
& \text { Included in contingent - } \quad-\quad \text { - } \quad-\quad \text { 137,676 }-44.90 \\
& 306,622 \quad 100 \cdot 00
\end{aligned}
$$

The deficiency was caused by the fact that several of the cantons were unable to furnish the number arsigned to them. Out of the 137,676, 20,239 were deducted as having already joined the army or the navy; and 2,768, being students for holy orders, \&c. were dispensés. 1,387 were allowed to remain at home as the sole support of their families; 257 were struck off on account of deaths, errors, \&c.; 525 were found unfit after joining ; 2,016 absented themselves, and were declared refractory "insoumis"; and 5,100 were incorporated into the navy.

The total number of new recruits actually available was thus reduced to 105,388 .

It is worthy of remark, that in $\mathbf{1 8 5 8}$ the number inscribed was only 305,943 . Conscripts living within the same canton and belonging to the same class may exchange tickets : this is termed "substitution," and the number who availed themselves of it was 718. A conscript may also be "replaced" by a relative, but the remplacent must not be over 30 years of age, or 35 if he has previously served in the army.

There were 16,173 cases of remplacement in 1855 .

Exoneration from serving may be purchased by the payment of about 92l. into the Caise de la Dotation de l'Armée. The fund is employed in 
granting bounties and extra pay as an inducement to volunteer, or to reinlist into the army.

The following clases are thus eligible for admission :-

Voluntecrs after four years' service, conscripts within one year of being unconditionally liberated, and others who have completed their term of service. These receive a bounty of 401 . on first joining, and a similar sum on completing their engagement of seven years, besides 1d. a day extra pay while serving.

The number of these engagés and rengagés in 1855 was 16,676 , in 1858 21,955 .

The term of service in the French army is seven years, of which, however, not above four are usually passed with the regiments.

The Imperial Guard is recruited by soldiers who have served meritoriously in the line for at least two years.* The Zouayes, Turcos, Chasseurs d'Afrique, Spahis, and Foreign Legion are recruited by voluntary enlistment.

The ordinary annual contingent in time of peace is 100,000 men. 'This is estimated to give an effective augmentation to the army of about 85,000 .

Prior to 1860 the price of exoneration was only $80 \mathrm{l}$. It was raised to $92 l$. in consequence of the large and annually increasing number of conscripts who purchased exemption from serving. 'These in the year previous amounted to 38,323 , or 27 per cent. In 1858 the proportion was 18 per cent., and in 1856 and 1857 only 16 per cent.

The standard leights for the different branches of the service were fixed by an Imperial decree of the 13th April, 1860, to be as follows :Cuirassiers, minimum, 5 feet 8 inches; dragoons and lancers, 5 feet 6.5 inches to 5 feet 8.4 inches; artillery, minimum, 5 feet 6.5 inches; chasseurs and hussars, 5 feet $5 \cdot 3$ inches to 5 feet $7 \cdot 8$ inches; infantry of the line, chasseurs à pied, \&c. minimum, 5 feet 1.4 inch.

In enumerating the French army, we may commence with the squadron of the Cent Gardes, numbering 221, with 179 horses : these form the Imperial escort on all occasions. The splendour of their appearance is only equalled by the thorough efficiency of their arms and equipment. Every man carries a brecch-loading rifle that has an effective range of 1200 yards, and a long, straight, double-edged sword. The latter is contructed so as to fix to the end of the rifle, and thus form a lance.

The Imperial Guard forms a complete corps d'armée in itself. It is composed as follows:-

1 Regiment Gendarmerie.
7 " Grenadiers and Voltigeurs.
1 " Chasscurs.
1 Squadron Gendarmerie \& Cheval.
6 Regiments Cavalry.
15 Batteries of Artillery.
2 Companies of Pontooneers.
2 " \#ngineers.
4 Train.

Its total establishment is 38,060 men, 13,447 horses, and 90 guns.

* A decree of the 27th April, 1860, authorises men who have not served to be receired into the Imperial Guard, provided their character and physical qualities are satisfactory. 
The Infantry consists of-

103 Regiments of the line, each having 3 active battalions, and 1 depôt battalion.

20 Battalions Chasseurs.

3 Regiments Zouraves.

2 " Foreign Infantry.

3 Battalions of African Light Infantry.

3 Regiments of Turcos, or Tirailleurs Algériens.

The Foreign Infantry, African Light Infantry, and Turcos are generally stationed in Algeria.

The first of these are recruited by roluntary enrolment, and are composed of stray individuals from every country in Europe, questions as to character not being asked.

The African Light Infantry is a disciplinary corps, and receives into its ranks such soldiers as incur a punishment involving more than three months' imprisonment: by subsequent good conduct, however, they may entitle themselves to be retransferred into their original regiments. Any man misconducting himself whilst in the African Light Infantry, renders limself liable to be sent into the "compagnies disciplinaires" of the colonies, stationed in the West Indies, Senegal, the Islnnd of Réunion, and Ocennia.

The 'Turcos, or Tirailleurs Algériens, are recruited by voluntary enlistment. The officers, and most of the non-commissioned officers, are French, the men being natives of Algeria. They took part in the Italian campaign of 1859 , but showed so turbulent a disposition in the march from Genoa, that it was found necessary to take the ammunition from their pouches. At Solferino they robbed the packs of a regiment that had taken them off in order to make a charge, and I suppose a collection of greater ruffians could hardly be met with anywhere.

The French Cavalry numbers 58 regiments, and is 70,000 strong. It is divided into light, line, and heavy. The latter wear the cuirass; but it is, I believe, contemplated to make the whole of the French cavalry Light, and to arm every man with a rifle of long range.

In noticiug this arm of the service, I should not omit the three regiments of Spahis, who are, with the exception of the officers, natives of Algeria, and are equipped in the Arab fashion. The saddles have backs as high and commodious as an easy chair; their arms consist of a sword secured under the left saddle flap, and a long rifle slung across their back. They are, of course, innocent of the tracasserie of a European soldier's kit, and as they ride along, enveloped in the folds of an ample red cloak, look not unlike Welch women going to market.

The French Artillery is composed as follows:-

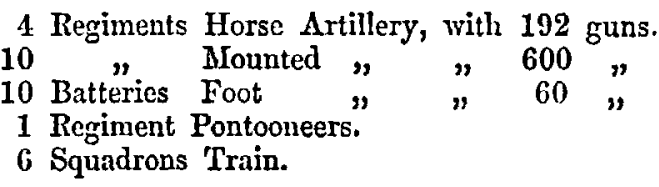

Giving a total of 38,767 men, 37,954 horses, and 852 guns-this, is in 
aldition to 15,000 garrison Artillery, and the depôts, artificers, \&c.-so that the total number of guns that can be brought into the field, including the Imperial Guard, is 942.

The guns are of brass, and are all rifled; every exertion is being made to render the matériel as perfect as possible; but I must add that the French say they consider their brass muzzle-loading guns, such as were used in Italy, nore serviceable and effective than our Armstrongs-an opinion hardly endorsed on this side of the Channel.

Among the military powers of Europe we must unquestionably accord to France the first place. Her army, it is true, is numerically inferior to that of either Russia, Austria, Prussia, or the probable future army of Italy; but morally and practically she is almost, if not quite, a match for any two of them. The Russian forces are scattered over a vast area, and composed in a great measure of a labyrinth of tribes of Cossacks, who are, from their constitution, moveable only to a very small degree; and the want of railway communication, and of even good roads, cause the concentration of any considerable force to be a work involving great time and labour, to say nothing of expense, always a very important item in military calculations. Austria, too, has a large army, and no pains have been spared by the government to make it as efficient as possible. . But, on the other hand, it is composed of many nationalities, speaking different languages, and having in some instances no political sympathies with the Imperial Government. In proof of this, I may state that at Solferino several regiments of Croats marched off the ground in good order, refusing to draw a trigger against the allies. Prussia and Germany are, indeed, united in interests and sympathies, but they are divided into a number of fractions, each ruled over by its own petty prince. In case of war the authority of these must fade away, and that of the Federal power come to the front, ere the German forces could, as a united body, take the field.

In France none of these adverse conditions exist. Every Frenchman feels a pride in the conscionsness of his nationality, the French language is nearly universal, her territories are compact, and traversed in every direction by a network of railways laid out so as carefully to meet every strategical contingency, and clusters of strong fortresses line the frontiers from the British Channel to the MIcditerranean. Algcria, so profitless as a colonial possession, furnishes an excellent practical school of campaigning. The troops of all arms, which I had excellent opportunities of observing, when they were concentrated at the grand reviews held on the occasion of the Emperor's visit to his African dominions last September, had a highly soldierlike and servicenble appearance. The French superior officers are practised in handling troops in large masses, and the men themselves are taught to be constantly ready to move at the shortest notice, every man having his tente alabri, his cooking utensils, and camp equipment, as part of his liit, and he never appears on parade without them.

The events of the spring of 1859 may serve as an example of the extraordinary rapidity with which a French army can be assembled, and directed upon any given point. Then we saw how, with scarcely any warning, with hardly a single note of preparation, 200,000 men, armed and equipped with every modern appliance, were poured into the plains of Lombardy. Eyen this performance, however, did not satisfy the French 
Emperor; for at that time, in spite of all precautions, the collection of clothing, fuel, and warlike stores, in the French magazines, and the activity prevailing in the arsenals, could not be concealed. The Moniteur, we know, inserted the most laboured articles to prove that the "apparent movement" was only due to the fact of the stores having fallen rather below their usual level, and its columns vented violent invectives against those who hinted that warlike preparations were in progress, which, supported by the Imperial speech on opening the Chambers, ought to have reassured all reasonable people; but these efforts were not entirely successful. In order, therefore, to secure for France the ntmost advantage in point of time on any future occasion, a decrec was issued soon after the termination of the war, ordering the intendance to collect and to keep on hand such supplies of clothing, shoes, camp equipage, and every species of matériel, that the French army could be placed upon a war footing, and put in motion, without previously attracting notice at home or abroad.

I may, perhaps, be asked, What number of troops could France at present bring into the field ? The French official returns show that on the 1st of January, 1860, the number of available men was as follows:-

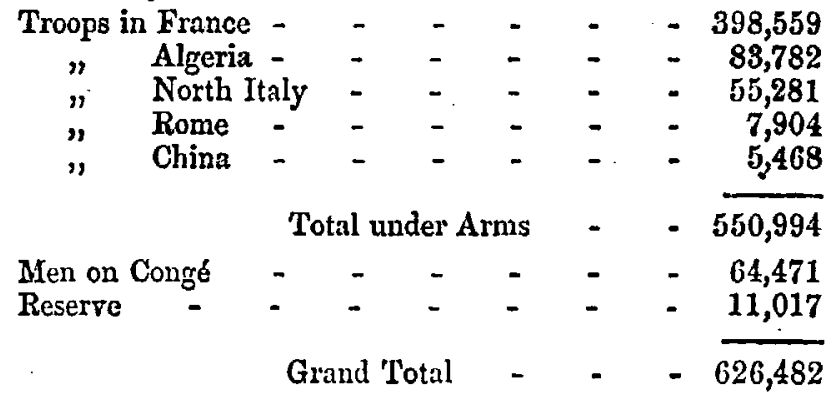

In the event of a European war we may assume 150,000 to be required for garrisons, depôts, artificers, civil forces, \&c. and 60,000 for Algeria. Thus, the actual number of men that could be brought into the field, would be in round numbers something over 400,000 . These figures are, of course, exclusive of National Guards, or any extraordinary levies.

\section{Great Britain.}

The army of Great Britain is recruited entirely by voluntary enlistment, and the whole of the British troops composing it are enlisted in the United Kingdom, with the exception of the 100th Reginent of the line, lately raised in North America.

Our present establishment is as follows:-

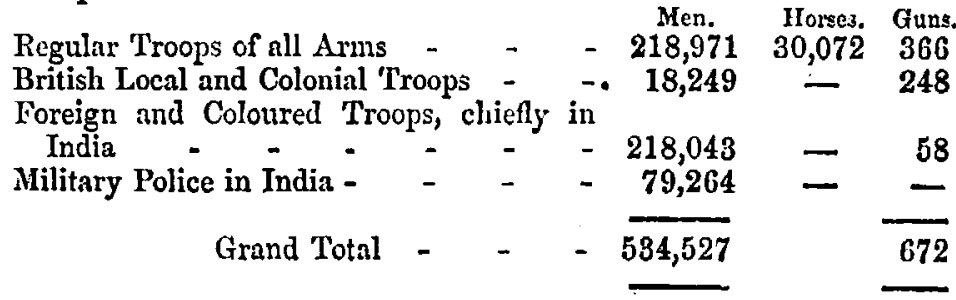


Of this force, however, only a very small fraction is in the United Cingdom. At the present moment the forces in England, Scotland, and Ireland are-

$$
\begin{aligned}
& \text { Men. Guns. } \\
& \text { Infantry-Guards, } 7 \text { Battalions - - } \quad \text { - 6,297 } \\
& \text { " Line, } 35 \text { " - - - 33,105 } \\
& \text { - Total - _ } \quad \text { - } \quad-\overline{39,402} \\
& \text { Cavalry..-Life and Horse Guards, } 3 \text { Regiments } 1,311 \\
& \text { " Dragoons, \&c., } 16 \text { Regiments - - 10,560 } \\
& \text { Total - - - - - } \overline{11,871} \\
& \text { Artillery.-Horse, } 6 \text { Batteries - } \quad \text { - } \overline{1,200} 36 \\
& " \text { Field, } 23 \text { " - } \quad-\quad \text { - } 5,060138 \\
& " \\
& \text { - } \frac{4,680}{10,940} \frac{-}{174} \\
& \text { Engineers - - - - - } \quad \text { - } \quad \text { - } 2,316 \\
& \text { Military Train - } \quad \text { - } \quad \text { - } \quad \text { - } \quad \text { - } \quad \text { - 1,830 } \\
& \text { Hospital Corps - } \quad \text { - } \quad \text { - } \quad \text { - } \quad \text { - } 609 \\
& \text { Commissariat Staff Corps - } \quad-\quad-\quad 300 \\
& \text { Grand Total, Active Forces - } \overline{67,268} \overline{174}
\end{aligned}
$$

Besides, there are the Depôt Establishments, as follows:-

$$
\begin{aligned}
& \text { Infantry, Line, } 126 \text { Depôts } \quad-\quad \text { - } \quad \text { - 24,770 } \\
& \text { Cavalry, " } 9 \text { " } \quad \text { - } \quad \text { - } \quad \text { - } \quad \text { - } 396 \\
& \text { Artillery - - - - - - - 2,975 } \\
& \text { Total Depôts - - - } \quad \text { 28,141 }
\end{aligned}
$$

Reserves available for the defence of the kingdom in case of war:-

$$
\begin{aligned}
& \text { Pensioners - - - - - - - } 14,768 \\
& \text { Militia - } \quad \text { - } \quad \text { - } \quad \text { - } \quad \text { - } \quad \text { - } \quad \text { - } 45,000 \\
& \text { Yeomanry - - - - - - - } 16,080 \\
& \text { Irish Constabulary } \quad-\quad-\quad-\quad-\quad-12,392 \\
& \text { - Volunteers - - - - } \quad \text { - } \quad \text { - } \quad \text { - } 140,000 \\
& \text { Total - - - - }-\overline{228,240}
\end{aligned}
$$

A glance at these figures shows that our military establishments bear no proportion in point of numbers to those of the continental powers, and that our forces at home are no more than sufficient to furnish the necessary reliefs for our colonial garrisons. Of reserves of regular trained troops we have actually none, and when any emergency occurs, we can only fill up the ranks of our regiments with raw recruits, by the slow process of enlistment. 
Wre may, perhaps, be disposed to envy the wonderful elasticity of the personnel possessed by the great military monarchs of Europe, the stroke of whose pens call up trained soldiers in round hundreds of thousands at a time; but when we come to analyse the cost at which this is achieved, the bill proves a heavy one, and do we not sec more than one of the great European powers scarcely able to stand under the weight and burden of their military establishments? The limits of a lecture forbid me to enlarge upon this interesting and important branch of the subject, hut I must nevertheless be permitted to remark that the sum total of the military and naval budgets, or the per-centage of the genernl revenue absorbed by them, afford but very imperfect data for draving a parallel beticeen the pressures actually entailed upon the resources of different countries, and it would be equally fallacious to divide the number of pounds expended in a year by the number of men kept up, and to take the results as any relative criterion of the economy of different administrative systems. It rould be difficult to reduce to figures the actual commercial loss, and the drain upon the general prosperity of a nation, to say nothing of the social inconvenicnce that is entailed by the system of compulsory service-in fact we may take it as an axiom, that if, like Cadmus, we sow dragon's tecth, and regard the crop as one of our staples, we shall find it the most exhausting to the soil of any we can cultivate. The amount of desertion prevailing in the British Army is a favourite topic with French authors, when trying to disparage our military institution; they point contemptuously to our men, whom, they say; are only to be bribed to serve by a vicious system of bounties, and then turn round exultingly, telling us to look at France, where all embrace the noble career of arms, from the peer to the peasant! Well, so they do; not from choice, horrever, but because they cannot help themselves. They, too, would desert, but the police and gendarmerie are too sharp for them, and desertion is a game with edge-tools on the other side of the Channel.

I feel sure that I do not exaggerate when I say that the word " conscription" carries terror and dismay to every town, village, and homestead of the whole continent of Europe. So severely did it press on the French nation during the First Empire, that, though the salaried dependents of the Emperor voted all his demands for men most obsequiously, and the press were lavish in their cncomiums on his measures, it was not without extreme difficulty and excessive rigour that the conscription could be carried into execution, particularly in the rural districts; and everybody was forced to serve, unless their bodily infirmities rendered them quite holpless.

Exemptions were at first allowed to be purchased for 300 francs, but this privilege was soon repealed, and in the latter days of the Empire a substitute could not be procured for less than $\mathfrak{f 0 0}$ to $£ 1,000$.

Those who, after being drawn, failed to join the army within the prescribed time, were deprived of their civil rights, and denounced to all the gendarmerie in the empire as deserters. Depôts were appointed for the punishment of the refractory, where they wore the uniform of convicts, and were employed to labour on public roads without pay.

The terrors of this treatment being at length found insufficient to bring the conscripts to their colours, it was decreed that a deserter, or a person 
who failed to attend, should be fined 1,500 francs, and condemued to three years' hard labour in the interior, with his head shaved, but the beard long. If he deserted from the army, his punishment was to be undergone in a frontier place, where he was sentenced to hard labour for ten years on bread and water, with a bullet of 8lbs. weight chnined to his leg.

This was the mereiless way in which the French army was recruited; nor can we wonder that such laws were required, when we find that in the ten years the Empire lasted, no less than 2,300,000 additional conscripts were enrolled, of which number 2,200,000 perished. In 1813 it was not an uncommon sight to witness gangs of conscripts being marehed in chains to their depôts.

It will, of course, be said that I am resuscitating events of half a century since, and that in the present day the service in France is decidedly popular. Let the returns of 1859 speak for themselves. TVe find that in that year no fewer than 38,323 conscripts, or 27 per cent. of those drawn, paid 80l. each, to purchase exemption from serving; and, though the whole of this sum was paid to volunteers willing to engage for seven years, the number of the latter was only 16,372! The Minister of War, rather comically, sings a dirge in the columns of the Moniteur orer the declining love of the noble profession of arms on the part of the youth of France, and then gives the screw another turn by raising the price for exoneration to $92 l^{*}$

"Comparisons," as Mrs. Partington says, "ure olorous;" but, while speaking of foreign armies, and the military systems of different countries, it may be amusing to glanee at the opinions of foreign writers on England, few of which are very flattering to our national vanity.

M. Wickede, a German author, in a work published in 1856 , called the "Vergleichende Charackteristik" of the Austrian, Prussian, English, and French armies, devotes a long article to criticizing our army. The English officer he describes as nothing but a fine gentleman, who knows but little, and cares less, for his duties, whose only study is his "studboock," by which I presume he means the betting-book, and who is hardly ever seen in regimentals, but esteems plain clothes or hunting costume more honourable than Her Majesty's uniform. In fact, he says that the generality of our officers, even those in command of regiments, are so inefficient that they would never be more than corporals in the French or Prussian army. The English soldier he admits to be brave, but says he is utterly helpless in the field.

iI. Wickede apparently anticipates criticism, and lest his readers should call to mind the many laurels won by English armies, he very patriotically insists that the Duke of Wellington owed all his successes to the German element in the Peninsular armies; the whole of the outpost duties, he says, fell to their lot-in fact, his countrymen did all the work, and showed the English troops the way to victory!

ii. Couturier de Vienne, chef d'escadron d'Etat-Major in the French scrvice, in his work on the military forces of the principal powers of Europe, while noticing M. Wickede's publication, states that he thinks it

* A decree of the 8th April last further raises the sum to be paid for exoneration to $100 l$, volunteers receiring 881.1

VOL. V. 
is perhaps going a little too far, to say that English officers are hardly fit to be made corporals of, but gives it as his opinion that they think military duty a sort of degradation, and are much more at home at the "Jockey Club." He further says that our infantry are composed of starving Irishmen and labourers out of work, and our cavalry of thieves and pickpockets collected out of the streets of London or Birmingham. With a spirit of thorough misrepresentation, he adds that we had to send navvies to the Crimea to make the trenches and approaches to Sebastopol, and that in India a native servant must be kept for every trooper to groom his horse and clean his arms and equipments.

Now, it is, perhaps, hardly necessary to observe, that the navvies were sent to the Crimea to construct, not the trenches or batteries, but the railway from Balaklara to the front. As to the grooms to attend on our cavalry soldiers in India, he might have added that the infantry have their packs carried for them on the line of march; not because the men are too lazy and undisciplined to do their duty but because their energies and lives are considered as too valuable to be thrown away, or exhausted in any labour that can reasonably be saved, in that trying climate.

M. Colonjun, writing in the Spectateur Militaire for May, 1859, makes the following highly charitable remarks:-

"England has now passed through the first three epochs of her existence, and is rapidly on the wane. True it is that she tries hard to lide her grey hairs under a brown wig, but anyone can see that her feet are gouty, and that decline is strongly marked over her whole system! This quondan queen of the seas seems to forget that, if genius founds empires, selfishness destroys them."

Lieutenant-Colonel Charles Martin, of the Third Lancers, in an article on the French possessions in the Eastern seas, follows up this in another number of the Spectateur", by saying that, "as England is evidently failing, the time is coming to make her surrender her ill-gotten possessions," and suggests that the Mauritius should be wrested from us, pointing out that the population, being French, would certainly join an invading force, and France would have her own property again.

The same writer, in an article upon the English military institutions, draws a comparison between the English and French civil forces, and notices the extraordinary respect for authority that exists in England, as shown by the fact of our police being wholly unarmed. "But," he says, "will this continue? No! ere long the people of England will recognise their rights, and will no longer be trampled upon by a cruel, selfish, and tyrannical aristocracy. 'Then England will know the same commotions that have agitated other nations, and the people, freed from the chains that have bound them, will not be restrained by policemen or constables, but fall into the most frightful excesses. Should such a calamity overtake England, her army, rearganised upon a solid, but at the same time, liberal basis, will be her sole anchor of safety. The double mission that it will have to fulfil will not differ in any respect from that of continental armies, instead of playing the 'rôle oisif et incomplet' that it does at present in the United Kingdom."

Colonel Charles 'Martin's recipe for making the country a perfect 
elysium, is evidently to have a conscription, and 500,000 idle soldiers garrisoning our towns, with a guard-house at the corner of every street; possibly a corps of drummers beating the tattoo down Regent-street every evening; our police turned into gendarmerie on the French model, with waxed mustachios, and all the other delightful attributes of a "strong" yovernment. I am afraid, however, that it will be some time before John Bull, notwithstanding the good sense for which Colonel Martin gives him credit, will rise to avenge the injustice and cruelties heaped upon him by the "imperious upper classes," and that he will in the meantime receive the worthy colonel's propositions with the same diffidence that the fores cxhibited when their comrade, who had lost his brush, suggested that they would be much more comfortable if they would part with theirs.

I have selected these extracts quite promiscuously, and could multiply them to any extent, to show the strain of sentiment generally indulged in by continental writers, when treating of England. It would not be easy to say whether ignorance or wilful misrepresentation predominates in them; but it hardly adnits of a doubt that an aggressive spirit is thus fostered against Eugland and Englishmen.

But though the columns of the Moniteur de L'Armée, and other French journals, teem at intervals with tirades against the selfish policy of Britain, or sneers at our noble Volunteer movement, though foreign writers may be offended because our officers are gentlemen, and French colonels vapour about Chartist insurrections, -in spite of their mutual congratulations on the decadence of our empire, in their hearts they well know that the British lion has not yet lost his teeth or his claws.

France gocs to war for an idea, or draws the sword for honour and glory: England shields the weak and the oppressed, exerts her influence, and, if necessary, lavishes her treasure, and pours out her best blood, where the cause is just and righteous. And should the Tomple of Janus again be opened, her adversaries will find-if I may venture a parody on the poet's stanzas-that

Britannia has her bulwarks

In spirits bold and free;

Her marshall'd sons the foe will meet

On land as well as sea.

The meteor flag of England

Can still terrific burn;

And proudly shall her banner float

'Till with honour peace return."*

- Original lines:-

Britannia needs no bulwarks, No towers along the ateep;

Her march is o'er the mountain wares,

- Iler home is on the deep, *

The metcor flag of England Shall jet terrific born,

Till danger's troubled night depart, And the star of peace return. 